\title{
Diversity of the Aquatic Vegetation in the Irrigation Canals of Mulya Sari village, Banyu Asin Regency, South Sumatra
}

\author{
Wiwik Septiani $^{1 *}$, Siti Masreah Bernas ${ }^{2}$, Yuanita Windusari ${ }^{3}$ \\ ${ }^{1}$ Department of Environmental Management, Graduate School of Sriwijaya University, Jl. Padang Selasa, No. 524, Bukit Besar Palembang, South Sumatra, Indonesia \\ ${ }^{2}$ Department of Agriculture, Sriwijaya University, Jl. Palembang Prabumulih, Km. 32, Ogran Ilir, South Sumatra, Indonesia \\ ${ }^{3}$ Department of Biology, Sriwijaya University, Jl. Palembang-Prabumulih, Km. 32, Indralaya, Ogan Ilir, South Sumatra, Indonesia \\ *Corresponding author: wiwikseptiani59@gmail.com
}

\begin{abstract}
Mulya Sari village in Banyuasin Regency is a sub-optimum tidal land with sulfuric acid characteristics which utilize irrigation canal to provide water used in household, fishing, and agriculture. Information on the diversity of aquatic vegetation in the Mulya Sari village is still not much. The purpose of this research to identified and analyzed the diversity aquatic vegetation in the irrigation canal of Mulya Sari village. The method used in this research is purposive sampling method. Aquatic vegetation data are collected trough direct study and using the square of the wooden frame size of $1 \mathrm{~m} \mathrm{x} 1 \mathrm{~m}$ (transect methode), then observation are made for identification. Environmental condition in the irrigation canal is still good, with the environmental parameters in the form of Temperature, DO, BOD, TSS, TDS and $\mathrm{pH}$ still meet environmental quality standard. The irrigation canal in Mulyasari village was found 7 species of aquatic vegetation belonging to 3 class of Liliopsida, 3 class Monocotyledoneae, and 1 class of Dicotyledoneae, with the value of diversity index between 0,57 - 1,53 and low diversity. Corellation Pearson between water quality and sediment characters of diversity has shown Temperature, DO, BOD, TDS and $\mathrm{pH}$ have corellation to diversity.
\end{abstract}

\section{Keywords}

aquatic vegetation, irrigation canal, water quality

Received: 19 February 2018, Accepted: 21 May 2018

https://doi.org/10.26554/sti.2018.3.3.114-118

\section{INTRODUCTION}

Mulya Sari village in Banyuasin Regency is a sub-optimum tidal land with sulfuric acid characteristics (Sodikin, 2012). Tidal land impact on the flooded some rice fields, which effect in some of chemistry, physics and biology related to soil and plants change (Diansyah, 2014), an irrigation canal was created to overcome it, like macro canal (primary and secondary) and micro canal (tertiary and quarter) (Suriadikarta, 2005). The impact of irrigation canal according to Budianta et al. (2012) is the formation of several land typologie with the water gate system "stoplog", to regulate excessive rainwater disposal during fertilization, rinsing and washing of toxic and acidic elements (Wirosoedarmo and Usman, 2002).

The environmental changes in sub-optimal areas according to Laoh (2002) such as surface erosion in rice fields due to uncontrolled and continuous using of fertilizer, Murtiono and Wuryanta (2016) added, it would negatively impact to the destruction of soil structure, disruption of organism balance and decreased water quality and increased weed growth, which have an indirect impact on the decline in agricultural production, increased acidity levels, affect to agricultural improvement activities, and disrupt human activities, such as flooding, irrigation canal dredging and disruption of human health.

Dennison et al. (1993) aquatic vegetation has a role in the nutrient cycle, sediment stability, and turbidity of water. Michael (1995) increased Nitrogen and Phosphorus in water will have an effect on the explosion of vegetation population. Based on the statement, there needs to be research to study and analyze how the diversity of vegetation aquatic in the irrigation canal of Mulya Sari village. The results obtained can be informed in managing irrigation canal in sub-optimal land, and the level of environmental changes that tend to be high.

\section{EXPERIMENTAL SECTION}

The research has been conducted in the irrigation canal with 8 (eight) stations in the Mulyasari Village of Banyuasin Regency, South Sumatera, in May 2016. The research location can be seen in Figure 1. There are 17 tertiary with an area of $800 \mathrm{~m}$ each tertiary at stations E, F, G, and $\mathrm{H}$ there are fishery, agriculture, livestock, and retention ponds. Village giving canal (SPD) at stations $\mathrm{C}$ and $\mathrm{D}$ with $3500 \mathrm{~m}$ wide utilize for household and main drainage canal (SDU) at stations A and B utilize for 
Table 1. Measurement of water quality parameters and sediment character

\begin{tabular}{cccccccccc}
\hline Station & $\begin{array}{c}\text { Temperature } \\
{ }^{\circ} \mathrm{C}\end{array}$ & $\begin{array}{c}\mathrm{DO} \\
(\mathrm{mg} / \mathrm{L})\end{array}$ & $\begin{array}{c}\mathrm{BOD} \\
(\mathrm{mg} / \mathrm{l})\end{array}$ & $\begin{array}{c}\mathrm{COD} \\
(\mathrm{mgL})\end{array}$ & $\begin{array}{c}\mathrm{TSS} \\
(\mathrm{mg} / \mathrm{l})\end{array}$ & $\begin{array}{c}\mathrm{TDS} \\
(\mathrm{mg} / \mathrm{L})\end{array}$ & $\mathrm{pH}$ & $\begin{array}{c}\text { N-Total } \\
(\%)\end{array}$ & $\mathrm{P}_{2} \mathrm{O}_{5}^{-}$Total $(\%)$ \\
\hline $\mathrm{A}$ & 31.52 & 4.03 & 2.93 & 13.33 & 36.67 & 462 & 4.77 & 0.23 & 0.1 \\
$\mathrm{~B}$ & 30.06 & 4.77 & 2.93 & 15.33 & 40 & 452 & 4.5 & 0.15 & 0.09 \\
$\mathrm{C}$ & 31.4 & 4.13 & 2.77 & 12.33 & 36.67 & 470.67 & 4.81 & 0.2 & 0.09 \\
$\mathrm{D}$ & 30.57 & 4.57 & 2.7 & 10.33 & 46.67 & 436.67 & 4.99 & 0.19 & 0.1 \\
$\mathrm{E}$ & 30.47 & 5.1 & 1.9 & 14.67 & 56.67 & 718 & 3.39 & 0.19 & 0.03 \\
$\mathrm{~F}$ & 30.1 & 5.33 & 1.7 & 17.67 & 53.33 & 693.67 & 3.96 & 0.24 & 0.04 \\
$\mathrm{G}$ & 29.92 & 5.67 & 1.67 & 18 & 53.33 & 745.33 & 3.84 & 0.23 & 0.07 \\
$\mathrm{H}$ & 29.89 & 6.2 & 1.57 & 18.67 & 26.67 & 1046.67 & 3.56 & 0.11 & 0.03 \\
\hline
\end{tabular}

public toilets and drainage canal.

Parameters of water quality (Temperature, DO, COD, BOD, TSS, and TDS) and sediment characters (sediment $\mathrm{pH}$, Nitrate, Phosphate and 3 fraction textures) determined by purposive sampling method. Sampling of plants by making square of wooden frames size of $1 \mathrm{~m} \times 1 \mathrm{~m}$ and plugged in irrigation canals (Tansect methode), the vegetation present in the square was recorded, documented, counted by type of each station and sample of plants taken to the laboratory for identification.

Data analysis of aquatic vegetation on irrigation canals was calculated by the Shannon formula (Odum, 1998).

$$
H^{\prime}=\Sigma p i \ln p i
$$

Where, $\mathrm{H}^{\prime}=$ Shannon - Winner diversity index; $\mathrm{Pi}=$ The ratio of the number individuals of a species to the whole type (ni / $\mathrm{N}) ; \ln =$ Natural logarithm

\section{RESULTS AND DISCUSSION}

Parameters of water quality and sediment characters result seen in Table 1. The parameters result that was the temperature in the irrigation canal of Mulya Sari village ranges from $29.89-31.52^{\circ} \mathrm{C}$ (Table 1 ) with low value in station $\mathrm{H}$ and high values in station $\mathrm{A}$. The temperature difference is not

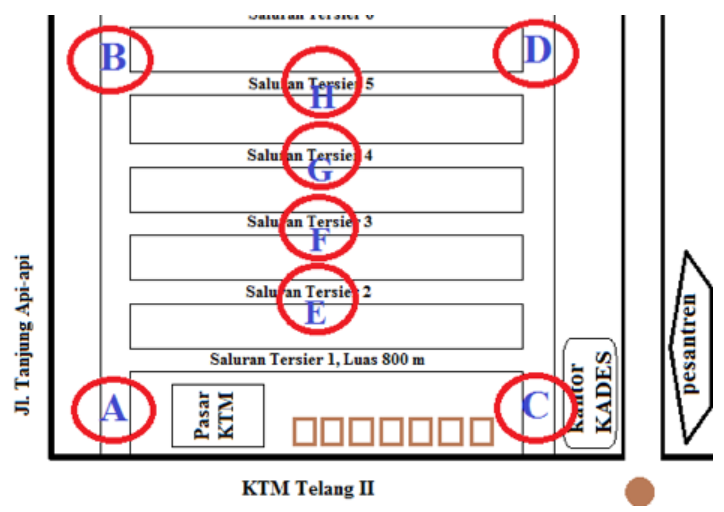

Figure 1. Sketch location of research point and sampling in Mulya Sari Village
Table 2. Proposition of soil sediment fraction in irrigation canal of Mulya Sari village

\begin{tabular}{lrrrc}
\hline Station & Sand & Silt & Clay & Texture classification \\
\hline A & 18 & 81.52 & 0.48 & Silt \\
B & 4 & 94.64 & 1.36 & Silt \\
C & 0.99 & 97.76 & 1.26 & Silt \\
D & 0.68 & 97.97 & 1.36 & Silt \\
E & 1.62 & 97.18 & 1.2 & Silt \\
F & 2.77 & 96.13 & 1.09 & Silt \\
G & 1.64 & 97.34 & 1.02 & Silt \\
H & 1.01 & 97.67 & 1.32 & Silt \\
\hline
\end{tabular}

very significant, since the research was conducted during the summer season, and influenced by high human activities in the irrigation canal thus contributing to the increasing temperature (Semiun, 2013). Based on Government Regulation No. $82 / 2001$ of water quality management and water pollution control, the temperature was natural state includes criteria of class 1 deviation 3 , its meaning the location of observations in the irrigation canal of Mulya Sari village is still good. Vegetation as a temperature stabilizer, the density of vegetation community that absorbs the intensity of light, and the water temperature becomes more stable (Marlina et al., 2017).

The DO values range from $4.03-6.20 \mathrm{mg} / \mathrm{L}$ (Table 1) with low value in station $\mathrm{A}$ and high value in station $\mathrm{H}$, the difference in DO values between stations is not significant. Sastrawijaya (2000) the life of aquatic organisms goes well when the dissolved oxygen content is at least $5 \mathrm{mg} / \mathrm{L}$. The high value of DO is also influenced by the absorption of oxygen into the water from the air, as well as from organic materials that are oxidized by microorganisms (Silalahi, 2009). Based on Government Regulation No. 82/2001, DO criteria class I with deviation 6 means the condition of the water is still good. Vegetation in the irrigation canal as a supplier of oxygen and CO2 absorber (Marlina et al., 2017), the DO values in the station $\mathrm{A}, \mathrm{B}, \mathrm{C}$ and are smaller due to the presence of vegetation in groups and low densities, whereas in stations $\mathrm{E}, \mathrm{F}, \mathrm{G}$, and $\mathrm{H}$ vegetation is diverse and high density. 
Table 3. Vegetation Diversity in irrigation canal of Mulyasari village

\begin{tabular}{llrrrrrrr}
\hline Species & A & B & G & D & E & F & G & H \\
\hline Liliopsida & & & & & & & & \\
- Cyperus distans & 178 & 17 & 212 & 48 & 97 & 6 & 37 & 15 \\
- Eleocharis dulcis & 0 & 113 & 0 & 87 & 88 & 91 & 46 & 117 \\
- Leersia hexandra sw & 14 & 41 & 7 & 101 & 19 & 19 & 19 & 15 \\
\hline Dicotyledoneae & & & & & & & & \\
- Nymphae alba & 0 & 0 & 0 & 0 & 70 & 77 & 39 & 45 \\
\hline Monocotyledoneae & & & & & & & & \\
- Hydrilla verticillata & 0 & 0 & 0 & 0 & 0 & 0 & 0 & 159 \\
- Eleocharis acicularis & 152 & 15 & 45 & 0 & 0 & 0 & 7 & 50 \\
- Eleusine indica & 0 & 0 & 0 & 0 & 3 & 3 & 2 & 6 \\
\hline
\end{tabular}

Table 4. Diversity Values (H') and Equitability (E) of the Aquatic vegetation

\begin{tabular}{ccccccccc}
\hline Index & A & B & C & D & E & F & G & H \\
\hline Diversity (H') & 0,83 & 1,06 & 0.57 & 1.05 & 1.31 & 1.12 & 1.52 & 1.53 \\
Equitability (E) & 0.76 & 0.76 & 0.52 & 0.96 & 0.81 & 0.69 & 0.84 & 0.78 \\
\hline
\end{tabular}

The BOD values range from 1.57 to $2.93 \mathrm{mg} / \mathrm{L}$ (Table 1) with value indicator $>2 \mathrm{mg} / \mathrm{L}$ in station $\mathrm{A}, \mathrm{B}, \mathrm{C}$, and $\mathrm{D}$, meanwhile station E, F, G, and $\mathrm{H}$ indicator $<2 \mathrm{mg} / \mathrm{L}$. Hastiana (2014) water pollution level with BOD indicator $<2 \mathrm{mg} / \mathrm{L}$ is still good. If related to water quality standard PP. 82/2001, BOD criteria class I deviation $2 \mathrm{mg} / \mathrm{L}$ is still good, which according to Agus et al. (2017) organism can still live with these conditions, including aquatic vegetation.

That COD value range from $10.33-18.67 \mathrm{mg} / \mathrm{L}$ with low value in station $\mathrm{D}$ and high value in station $\mathrm{H}$. If related to water quality standard PP. 82/2001, COD criteria class I deviation $10 \mathrm{mg} / \mathrm{L}$, it means lightly contaminated. The high value of COD indicate organic matter or waste in the canals is difficult to be biologically degradation (Silalahi, 2009), meaning that the organic material in the irrigation canal still be biologically degraded by the organisms including aquatic vegetation, seen from station $\mathrm{E}, \mathrm{F}, \mathrm{G}$, and $\mathrm{H}$ COD value is higher, while in staiun A, B, C, and D, amount of COD was reduced.

The value of suspended solids (TSS) in irrigation canal ranges from $26.67-56.67 \mathrm{mg} / \mathrm{L}$ with loe value in station $\mathrm{H}$ and high value in station $\mathrm{E}$. Amount of suspended solids affects to the penetration and the turbidity, that inhibits the light entering the water, thus decreasing the amount of light for the vegetation doing photosynthesis (Odum, 1984). If related to water quality standard PP. 82/2001, station H criteria class I with a value $50 \mathrm{mg} / \mathrm{L}$ its still good, while station $\mathrm{E}, \mathrm{F}$, and $\mathrm{G}$ class II is lightly contaminate. According to Marlina et al. (2017)the value of TSS in the dry season is more normal, where TSS will be more quickly suspended because it was influenced by water flow and vegetation density.

The value of dissolved solids (TDS) in irrigation channels ranged from $436.67-1046.67 \mathrm{mg} / \mathrm{L}$, with low value in station
Table 5. Result of Pearson Correlation between parameters with vegetation diversity

\begin{tabular}{cccc}
\hline No & Parameters & $\begin{array}{l}\text { Correlation } \\
\text { value }(\mathrm{c})\end{array}$ & $\begin{array}{l}\text { Significance } \\
\text { and opprtunity }\end{array}$ \\
\hline 1 & Suhu & $-0,841^{* *}$ & $\mathrm{P}=0,009$ \\
2 & DO & $0,916^{* *}$ & $\mathrm{P}=0,001$ \\
3 & BOD & $-0,808^{*}$ & $\mathrm{P}=0,015$ \\
4 & COD & 0.705 & $\mathrm{P}=0,051$ \\
5 & TSS & 0.219 & $\mathrm{P}=0,602$ \\
6 & TDS & $0,801^{*}$ & $\mathrm{P}=0,017$ \\
7 & pH & $-0,800^{*}$ & $\mathrm{P}=0,017$ \\
8 & Nitrat & -0.305 & $\mathrm{P}=0,463$ \\
9 & Fosfat & -0.661 & $\mathrm{P}=0,074$
\end{tabular}

* Significant correlation on $\alpha=0,05,{ }^{* *}$ Significant correlation on $\alpha=0,01$

$\mathrm{D}$ and high value in station $\mathrm{H}$, according to Fitra (2008) the higher of TDS value, the light penetration will be inhibited. If related to water quality standard PP. 82/2001, TDS criteria class I is still good with deviation $1000 \mathrm{mg} / \mathrm{L}$, whereas criteria station $\mathrm{H}$ is lightly contaminate.

The degree of acidity $(\mathrm{pH})$ ranges from $3.39-4.99$. The $\mathrm{pH}$ value at the station has the acidity, the vegetation resistant to acidic environments such as Eleocharis dulcis (Susilawati and Nursyamsi, 2014). If related to water quality standard PP. $82 / 2001$ based on the natural environment $\mathrm{pH}$ classified its still good.

The N-Total ranges from $0.11-0.24 \%$ or $1100-2400$ $\mathrm{mg} / \mathrm{L}$. (Michael, 1995). Nitrate is the last oxidation of ammo- 
nium and ammonia derived from fertilization and dosmetic waste. The value of N-Total is high because it found cultivated ponds, cattle pens and places toilets. If related to water quality standard PP. 82/2001, its mean dangerous status.

The $\mathrm{P}_{2} \mathrm{O}_{5}^{-}$Total ranges from $0.03-0.10 \%$ or $300-1000$ $\mathrm{mg} / \mathrm{l}$. If related to water quality standard PP. 82/2001, its mean dangerous status. Vegetation at station E, F, G, and $\mathrm{H}$ with high $\mathrm{N}$ and $\mathrm{P}$ conditions of growth abundant and high density so that the amount of $\mathrm{N}$ and $\mathrm{P}$ in sediments is difficult to decompose, whereas in stations $\mathrm{A}, \mathrm{B}, \mathrm{C}$ and $\mathrm{D}$ with low density vegetation, $\mathrm{N}$ and $\mathrm{P}$ are high due the accumulation of tertiary canal and human activities.

Based on the soil texture of sediment in Table 2. Silt is the most fertile soil (Yamani, 2010), thats why there are many vegetation growing in this area. Silt is a soil texture that easily to erosion and degradation (Sitorus and Susanto, 2011).

\subsection{Diversity of Aquatic Vegetation}

The irrigation canal in Mulyasari village was found 7 species of aquatic vegetation (Table 3) belonging to 3 class of Liliopsida such as Cyperus distans, Eleocharis dulcis, and Leersia hexandram sw; 3 class of Monocotyledoneae such as Hydrilla verticillata, Eleocharis acicularis, and Eleusine indica; and 1 class of Dicotyledoneae such as Nymphae alba.

Class of Liliopsida have a high diversity index of all species community in all station, according to Acik and Sudarmadji (2017) the presence of vegetation from the Liliopsida class has been stabilized with conditions in this area.

\subsection{The Value of Diversity (H') and Equitability (E)}

The values of the diversity index $\left(\mathrm{H}^{\prime}\right)$ of aquatic vegetation found in the 8 irrigation canal stations with their equitability index $(\mathrm{E})$ seen in Table 4 . The aquatic vegetation diversity index ranges from $0.57-1.53$. According to Michael (1995) if $H^{\prime}=0-2.302$ vegetation diversity is low; $H^{\prime}=2.302-$ 6.907 moderate vegetation diversity, and $\mathrm{H}^{\prime} \geq 6.907$ high vegetation diversity. This means the diversity of vegetation in the irrigation canals of Mulya Sari Village is low. There was supported by the habit of farmers who always clean the irrigation canal when the harvest season is over (Kurnia, 2004). Equtability (E) value ranges from 0 - 1, the value of Equitability shows a obvious equitability. The population in the irrigation canal is not found dominant aquatic vegetation, meaning that the vegetation growth in the canal does not dominate each other.

\subsection{Pearson Corellation}

The correlation test results of temperature, $\mathrm{BOD}$, and $\mathrm{pH}$ has a negative correlation see Table 5 . Where according to Hastiana (2014) the higher of the corellation value, then the lower of diversity. The high of BOD value indicates high amount of organic material. The increase of organic material in the water according to Fitra (2008) will lead to high level of eutrophication. The TDS and DO value have positive correlation, mening that if the number of TDS and DO increase then the diversity is also high. COD, TSS, N-Total, and P-Total have no significant correlation to vegetation diversity, this is because the COD, TSS, N-Total and P-Total parameter are still at threshold that can be tolerated by the growth of aquatic vegetation (Silalahi, 2009).

\section{CONCLUSIONS}

The environmental conditions in the irrigation canal of Mulya Sari village is still good, with the environmental parameters of DO, BOD, TSS, TDS, and $\mathrm{pH}$ still meet the environmental quality standards and the dominant soil texture is silt. The diversity of vegetation aquatic in irrigation canal of Mulya Sari village of Banyuasin Regency, with range of diversity value between $0.57-1.53$, its mean the diversity of vegetation in the irrigation canals of Mulya Sari Village is low. The equitability of aquatic vegetation between $0.52-0.96$, there are not dominant population. There are 7 species of aquatic vegetation belonging to 3 class of Liliopsida, 3 class Monocotyledoneae, and 1 class of Dicotyledoneae. Corellation Pearson between water quality and sediment characters of diversity has shown Temperature, BOD, and $\mathrm{pH}$ have negatif corellation of diversity, then DO and TDS have positif correlation of diversity.

\section{ACKNOWLEDGEMENT}

Thank to my lecture, my friend (Eka and Iqbal) and my little brother (Randy) who help and joined the investigation, made documentation, and observation in my reasearch. Thanks to my parent who have provided motivation and finance my research.

\section{REFERENCES}

Acik, R. and Sudarmadji (2017). Hubungan Faktor Ekologi Dengan Struktur Komunitas Tumbuhan Mangrove Teluk Pangpang Taman Nasional Alas Purwo. Jurnal Ilmu Dasar, 18(1); 61-64

Agus, M., Y. Pujiastuti, and Y. Windusari (2017). Diversiti of the dragonfly (odonata) as an indication of water quality. Journals of Science and Technology Indonesia, 2(4); 80-84

Budianta, D., Napoleon, and D. Ristiani, editors (2012). SRI di lahan pasang surut, Prosiding Seminar Nasional Fakultas Pertanian Universitas Bengkulu Menuju pertanian yang berdaulat

Dennison, W. C., R. J. Orth, K. A. Moore, J. C. Stevenson, V. Carter, S. Kollar, P. W. Bergstrom, and R. A. Batiuk (1993). Assessing Water Quality with Submersed Aquatic Vegetation. BioScience, 43(2); 86-94

Diansyah, A. (2014). Kajian kualitas air daerah irigasi sekampung batanghari (studi kasus pada blok tersier KBH1. Ki). Ph.D. thesis, Universitas Gadjah Mada. Yogyakarta

Fitra, E. (2008). Analisis kualitas air dan hubungannya dengan keanekaragaman vegetasi akuatik di perairan parapat danau toba. $\mathrm{Ph} . D$. thesis, Universitas Sumatera Utara, Medan

Hastiana, Y. (2014). Community Structure of Riparian Com- 
munity of Sematang Borang River of South Sumatera. Jurnal Eksakta, 14(2); 6-21

Kurnia, U. (2004). Prospek Pengairan Pertanian Tanaman Semusim Lahan Kering. Jurnal Litbang Pertanian, 23(4); $130-138$

Laoh, O. (2002). Keterkaitan Faktor Fisik, Faktor Sosial Ekonomi dan Tataguna Lahan di Daerah Tangkapan Air dengan Erosi dan Sedimentasi (Kasus Danau Tondano, Sulawesi Utara). Ph.D. thesis, Institut Pertanian Bogor

Marlina, N., H. Hudori, and R. Hafidh (2017). Pengaruh Kekasaran Saluran Dan Suhu Air Sungai Pada Parameter Kualitas Air COD, TSS Di Sungai Winongo Menggunakan Software QUAL2KW. Jurnal Sains ETeknologi Lingkungan, 9(2); 122-133

Michael, P. (1995). Metode ekologi untuk penyelidikan lapangan dan laboratorium (Terjemahan). Universitas Indonesia Press, Jakarta

Murtiono, U. and A. Wuryanta (2016). Telaah Eutrofikasi pada Waduk Alam Rawa Pening. In Prosiding Seminar Nasional Geografi UMS. pages 170-181

Odum, E. P. (1984). Dasar-dasar Ekologi. Diterjemahkan oleh Samingan, Y dan Srigandono, B. 1998. Universitas Gadjah Mada Press, Yogyakarta

Sastrawijaya, A. . (2000). Pencemaran Lingkungan. Penerbit Rineka Cipta, Jakarta

Semiun, G. C. (2013). Degradation of Riparian Tree Diversity on Spring Fed Drains and Its Impacts to Water Quality, East Java. The Journal of Tropical Life Science, 3(3); 120-126

Silalahi, J. (2009). Analisis kualitas air dan hubungannnya dengan keanekaragaman vegetasi akuatik di perairan balige Danau Toba. Ph.D. thesis, Universitas Sumatera Utara. Medan

Sitorus, S. R. P. and D. Susanto, B andHaridjaja (2011). Kriteria dan Klasifikasi Tingkat Degradasi Lahan di Lahan Kering (Studi Kasus: Lahan Kering di Kabupaten Bogor. Jurnal Tanah dan Iklim, 1(34); 66-83

Sodikin, E. (2012). Sistem pertanian terpadu, alternatif usahatani pada lahan sub optimal. In Prosiding Seminar Nasional PERHEPI Pengelolaan Agribisnis Pangan Pola Korporasi Pada Lahan Sub Optimal. pages 10 - 16

Suriadikarta, D. (2005). Pengelolaan lahan sulfat masam untuk usaha pertanian. Jurnal Litbang Pertanian, 24(1); 36 - 45

Susilawati, A. and D. Nursyamsi (2014). Gulma rawa sebagai biofilter di lahan pasang surut. Warta Penelitian dan Pengembangan Pertanian, 36(3); 8 - 10

Wirosoedarmo, R. and A. Usman (2002). Studi perencanaan pola tanam dan pola operasi pintu air jaringan reklamasi rawa Pulau Rimau di Kabupaten Musi Banyuasin Sumatera Selatan. Jurnal Teknologi Pertanian, 3(1); 56 - 66

Yamani, A. (2010). Kajian Tingkat Kesuburan Tanah pada Hutan Lindung Gunung Sebatung di Kabupaten Kotabaru Kalimantan Selatan. Jurnal Hutan Tropis, 11(29); 32-37 